\title{
Fra den orange til den grå Viktor Henrik Kaufholz
}

For almindelige ukrainere er korruptionen tema nummer et, to og tre. Den Orange Revolutions ledere tabte, ikke mindst fordi de blot lod korruptionen blive værre og brugte kræfterne på at bekæmpe hinanden

Det endte 2010, som det begyndte i 2004, nemlig med Viktor Janukovitj som vinder af det ukrainske præsidentvalg.

Dengang for godt fem år siden var der massiv valgsvindel, og båret af Den Orange Revolution fejede Viktor Jusjtjenko ved omvalg Janukovitj af banen. Demokraten slog dengang den Moskvavenlige apparatjik.

Men i mellemtiden har både Ukraine, Den Orange Revolution og Janukovitj forandret sig. Ukraine er takket være revolutionen blevet mere demokratisk med større pressefrihed end i de fleste andre tidligere sovjetrepublikker. Janukovitj har også befriet sig fra skabelonen som 'Kremls mand i Kijev'. Jusjtjenko og hans folk fik på den anden side hverken bekæmpet korruptionen el- ler stoppet de personopgør, der dominerer ukrainsk politik. Overgangen fra den 'orange' Viktor til den 'blå' Viktor er langt mindre skelsættende, end nogen kunne forudse i 2004. Til gengæld ser det ikke ud til, at valget har stoppet de næsten uendelige magtkampe i ukrainsk politik. Julia Timosjenko, der fik 45,5 pct. af stemmerne $\bmod 48,9$ pct. til Viktor Janukovitj, nægter at træde tilbage som ministerpræsident, hvis ikke der er flertal for en anden regering.

Ukrainsk politik er et indviklet og uendeligt spil om magt og det, magt kan bruges til: at berige sig. De enkelte dele af spillet er sjældent synligt indbyrdes forbundet, men man gør altid klogt i at holde øje med de kontrakter og aftaler, der i sidste ende kommer ud af det. 


\section{Korruption på ukrainsk}

Det kan da lyde som en smuk idé at bevilge nye briller til alle veteraner fra Anden Verdenskrig - cirka en million. Men hvorfor bestilles brillerne ikke efter en licitation blandt ukrainske leverandører? Hvordan kan nogle ministre fra deres skriveborde se, hvilke briller veteranerne har brug for?

Sligt generer ikke korrupte ånder, så brillerne blev uden videre dikkedarer via et ukrainsk postboksfirma bestilt i Kina. De fleste briller, 770.000 , forsvandt under transporten, og af resten passede kun få veteranerne. De ansvarlige måtte på græs et par år, men er tilbage i stillinger, hvor de igen er med til at bestemme over offentlige midler.

En helt igennem typisk ukrainsk korruptionssag, der blev afsløret af de stadigt mere og mere selvsikre og uafhængige medier.

Man går galt i byen, hvis man placerer de politiske partier eller blokke i Ukraines parlament, Verkhovna Rada, på en skala fra højre til venstre. Det nytter heller ikke at læse politiske programmer eller analysere større taler.

Derimod bliver man ikke så lidt klogere af at se på politikernes armbåndsure, foretrukne firehjulstrækkere og restaurantvaner.

I den synlige del af spillet er partierne samlet bag en eller flere stærke personligheder. Regionernes Parti, som Viktor Janukovitj leder, er en slags 'russisktalende amters sammenslutning'. I de amter taler man ikke bare russisk, man lever af stål og jern, og så begynder konturerne af grupperingen at tegne sig. På samme måde er ministerpræsident Julia Timosjenkos såkaldte blok 'de ukrainsktalende amters sammenslutning'. Her taler man ukrainsk, her er landbrug den dominerende erhvervsgren, og så er den massive brug af ukrainsk bonderomantik i Julia Timosjkenkos valgkampagne til at forstå.

Alle partierne er også forbundet til en eller flere stærke erhvervsfolk, de såkaldte oligarker. De ejer så igen aviser, radio- og tv-stationer, og optræder således i mere end én forstand som sponsorer for partierne.

Bag Viktor Janukovitj finder man først og fremmest Ukraines rigeste mand, stålmagnaten Rinat Akhmetov, og gasmilliardæren Dmitro Firtasj. Bag Julia Timosjenko, der selv må betragtes som oligark, finder man Vitalij Hajduk og Serhej Taruta, der som Akhmetov gør i jern og stål.

Nogle oligarker holder sig ude af det igangværende opgør. Det gælder bl.a. Viktor Pintjuk. Han er den tidligere præsident Leonid Kutjmas svigersøn og ejer flere tv-stationer, der har dækket valgkampen forholdsvis afbalanceret og fair.

Netop fordi de enkelte partier/ blokke/bevægelser står og falder med deres ledere, er de personlige opgør indædte. En leder uden magt 
er en leder uden nøgle til stats-, amts- eller kommunekassen.

Den første store berigelsesrunde i Ukraine - privatiseringen af erhvervslivet - er forbi, så i disse år gælder det især om at lægge beslag på jord. Det drejer sig om godbidder som den tidligere sovjetiske forsøgsvingård på Krim og fiskerikontrollens anlæg i naturreservater. $\mathrm{Og}$ det drejer sig især om klassiske investeringsobjekter i bycentre. Centralt beliggende kollegier og lejlighedskomplekser til handicappede gøres med et pennestrøg overflødige, og så er vejen banet for nye butikscentre.

Nyeste træ i korruptionsjunglen er kontrakter på driften af offentlige ejendomme. Der kan skam være gode penge for onklen i byrådet $\mathrm{i}$ Krementjuk i at hjælpe nevøens itfirma til monopol på levering af software til huslejeopkrævningen.

Når man bor i Danmark, der er et af verdens mindst korrupte lande, har man svært ved at forstå, hvordan det er at bo i et af de mest korrupte. Ukrainerne er fortvivlede, men har ikke noget valg.

Ifølge forfatningen har Ukraine et offentligt finansieret sygehusvæsen. Gratis behandling til alle. Alligevel er den syge - eller vedkommendes familie - nødt til først at finde et som regel meget, meget anonymt kontor, hvor sygehusets velfærdsfond holder til. Her findes en prisliste på alt fra lagner over piller og sprøjter til kirurgiske indgreb. Be- handlingen går først i gang, når afdelingen har set en kvittering fra velfærdsfonden. Ulovligt? Ja. Er det afsløret? Ja. Stoppes det? Nej.

Så for den menige ukrainer er korruptionen tema nummer et, to og tre.

\section{Demokratisk indsprøjtning}

Alligevel er ukrainsk politik ikke helt principløs, og Den Orange Revolution var en virkningsfuld demokratisk indsprøjtning. Der kæmpes ud til sidste finesse om valgloven, og princippet om frie og hemmelige valg sætter heller ikke den tidligere valgsvindler Janukovitj spørgsmålstegn ved. Han har for resten aldrig indrømmet sit ansvar for svindlen i 2004.

Alle partier er - $\mathrm{i}$ hvert fald offentligt - enige om nødvendigheden af en fri presse. Præsident Leonid Kutjmas små sedler til medierne om, hvordan de burde behandle sagerne, er fortid.

Da partierne nu er topstyrede sammenslutninger af personer med kompatible interesser, er ukrainske valgkampe helt, helt anderledes end danske. De udspiller sig næsten udelukkende i medierne og inddrager kun undtagelsesvis vælgerne. De langvarige 'orange' demonstrationer 2004 var undtagelsen, og netop derfor så effektive.

Netop på grund af valgsvindlen 2004 har internationale organisationer i årevis lagt pres på Ukraines 
parlament og præsidentembede for at få valgloven forbedret. Spillereglerne skulle være helt klare.

Det blev de nu ikke helt, men alligevel var de internationale valgobservatører nogenlunde tilfredse efter både første og anden runde. De har fundet en masse mindre uregelmæssigheder og sjusk, men ikke den frygtede systematiske valgsvindel.

"Gårsdagens afstemning var et imponerende eksempel på demokratiske valg. Dette valg er en sejr for alle i Ukraine", sagde Joao Soares, formand for OSCE's parlamentariske forsamling og observatørkoordinator, på et pressemøde 8 . februar.

Som et kuriosum ved man nu, at mobiltelefoner kan bruges til køb og salg af stemmer. Vælgeren fotograferer sin stemmeseddel med kryds inde i kabinen, folder stemmeseddelen sammen og lægger den helt normalt i stemmeboksen. Valgtryk? Ikke tale om. Vel ude af valglokalet sender vælgeren billedet til sin velgører og kan hæve dusøren ved kasse et.

Julia Timosjenkos lejr anfægtede i første omgang valgresultatet både ved appeldomstolen i Kijev, der behandler sager om regionale valgkommissioner, og ved Den Høje Forvaltningsret, der behandler sager vedrørende Den Centrale Valgkommission, men trak 20. januar klagerne tilbage.

Klagerne drejede sig om 1,5 million stemmer, så Timosjenko kunne, hvis retten havde givet hende med- hold, udligne forskellen på 880.000 stemmer mellem de to kandidater.

Den menige ukrainer regnede på forhånd med fiflerier. I en meningsmåling fra FOM-Ukraine midt i december udtrykte 68 procent, at de ikke regnede med et fair forløb af valget.

\section{Gensidigt had}

Både OSCE's og Europarådets valgobservatører er stærkt utilfredse med, at valgloven blev ændret mellem første og anden runde. Det drejer sig om antallet af tilforordnede for at godkende valgprotokollen. Det er efter alt at dømme et reelt problem i det politisk skæve land, hvor Janukovitj dominerer i øst og Timosjenko i vest. De har begge svært ved at finde folk nok på deres respektive 'udebaner', men ændringen gjorde det lettere at blokere for godkendelse.

Præsident Viktor Jusjtjenko overhørte alle protester og skrev loven under - efter alt at dømme udelukkende fordi Julia Timosjenko var imod, men ikke havde været i stand til at mobilisere sit flertal i parlamentet.

Ganske vist var de to kampfæller under Den Orange Revolution, men i dag hader de hinanden af et godt hjerte. Jusjtjenko kaldte på en pressekonference 16. februar udnævnelsen af Timosjenko til ministerpræsident for 'min allerstørste politiske fejltagelse'. (Hun har i hans præsi- 
dent tid været regeringschef februar-september 2005 og igen siden december 2007).

Ser man på tallene, havde de to kandidater, der begge har været i toppen af ukrainsk politik i 10 år, tilsammen mindre end halvdelen af vælgerne bag sig, da de gik ind i anden runde.

I første valgrunde 17. januar fik Viktor Janukovitj 35,3 pct. af stemmerne og Julia Timosjenko 25,05 altså tilsammen temmelig nøjagtigt 60 pct. Med en valgdeltagelse på 66,8 pct., har de end ikke halvdelen af befolkningen bag sig. Så man kan ikke lige frem tale om folkets yndlinge.

Andelen af vælgere, der stemte mod alle kandidater, steg fra 2,2 pct. i første runde til 4,4 $\mathrm{i}$ anden.

Efter flere meningsmålinger at dømme havde en 'ny' kandidat været i stand til at slå både Janukovitj og Timosjenko i anden runde.

Der var et par andre interessante detaljer ved første runde. For det første at sejrherren fra 2004, Viktor Jusjtjenko, måtte nøjes med 5,5 pct., og for det andet at rigmanden Sergej Tigipko nåede op på 13 pct.

Julia Timosjenko regnede hurtigt $\mathrm{ud}$, at Tigipko kunne bringe hende sejren $i$ anden runde og tilbød ham posten som ministerpræsident, hvis hun vandt. Men han skulle ikke nyde noget af at 'samarbejde' med den politisk hensynsløse regeringschef og har helt afgjort styrket sit omdømme i den mere og mere poli- tiktrætte befolkning ved at holde sig ude af slagsmålet før anden runde.

Tigipko skal man holde øje med ved det næste parlamentsvalg, som kan komme snart som en løsning på magtkampen mellem præsident Janukovitj og Timosjenko, der trods valgnederlaget ikke har gjort mine til at gå af.

\section{Fndret magtfordeling}

Som led i forliget om omvalg 2004 blev magtfordelingen mellem præsidenten, regeringen og parlamentet ændret. Så Janukovitj kan godt prøve at udnævne en ny regeringschef, men denne skal have flertal i parlamentet. Timosjenko havde før valget et om end usikkert flertal bag sig. Hun må regne med overløbere. Men selv om Regionernes Parti med 172 ud af 450 pladser er parlamentets største, har Janukovitj-fløjen langt til et stabilt flertal.

Viceministerpræsident Oleksandr Turtjinov, der går for at være Julia Timosjenkos højre hånd, sagde 11 . februar, at "det er meningsløst for regeringen at træde tilbage", hvis Janukovitj ikke kan skaffe flertal bag en anden regering. Julia Timosjenko har bestemt ikke tænkt sig at gå uden at give Janukovitj kamp til stregen og har allerede efter at have opgivet retssagerne om valgsvindel fundet et passende motto: 'Hellere offer end taber'.

Ukrainske analytikere regner med ugelange forsøg på at danne en Ja- 
nukovitj-venlig regering. Lederne af flere små partier - som parlamentsformand Volodimir Litvin - står til valgnederlag, ja måske til at ryge helt ud af parlamentet. Så fortalerne for at prøve at skaffe en Janukovitjvenlig regering ved nyvalg er ikke mange.

Først og fremmest findes de ikke i erhvervslivet, der i praksis holder de politiske partier i live. I hvert fald har ingen af partierne med undtagelse af Tigipko råd til at føre valgkamp for egne penge.

Erhvervslivet er som ukrainsk menigmand interesseret $i$, at den ny præsident og parlamentet får vedtaget en økonomisk kriseplan. Foreløbig har Ukraine end ikke en finanslov for 2010.

Ekspræsident Viktor Jusjtjenko siger, at det er Timosjenkos skyld, fordi hun ikke tør fortælle folk sandheden om statens økonomi. Janukovitj har da også bebudet et 'kasseeftersyn'.

\section{En vis økonomisk bedring}

Ukrainsk økonomi skrumpede 2009 hele 15 pct., mens underskuddet på statsbudgettet i år endnu er af ukendt størrelse. Nu er stålpriserne og dermed eksporten på vej op, men Den Internationale Valutafond har indefrosset et lån på 16,4 mia. USD. Det kommer først til udbetaling, når der ligger en økonomisk kriseplan. Et blandt få lyspunkter er, at Ukraine for en gangs skyld har betalt sin regning til Gasprom i tiden - endda på valgdagen 7 . februar.

Kriseplanen vil uundgåeligt bryde valgløfter fra begge kandidater. De har begge lovet højere pensioner og bedre offentlig service. Det bliver der ikke noget af. Tværtimod må selv de fattige pensionister indstille sig på en større varmeregning, fordi staten ikke har råd til at subsidiere gassen.

En helt tredje udgang på den politiske krise kan blive et forlig mellem Janukovitj og Timosjenko. Det kan se paradoksalt ud efter måneders indbyrdes tilsvining, men faktisk var de to tæt på en politisk aftale sommeren 2009. Den faldt på, at Timosjenko ikke ville give præsidentposten til Janukovitj. Den detalje er nu afklaret.

Viktor Jusjtjenko faldt i folkets unåde på indenrigspolitikken og på hans svigt, når det gjaldt bekæmpelse af korruptionen, som i stedet blev værre $\mathrm{i}$ hans tid ved magten.

Han var udenrigspolitisk udpræget orienteret mod vest - mod EU og NATO. Han støttede verbalt Georgien under den korte krig om Sydossetien i august 2008 og irriterede ustandselig russerne ved at fremhæve, at russerne har undertrykt ukrainerne, ikke bare i sovjettiden, men også i tsartiden.

Jusjtjenko havde et yderst anstrengt forhold til både Putin og hans efterfølger på præsidentposten, Dmitrij Medvedev. 


\section{Oligarkerne siger fra}

Men den nøglebegivenhed, der for alvor stoppede al diskussion om Ukraines tilnærmelse til Rusland fandt sted længe inden Den Orange Revolution, nemlig i Rusland 25. oktober 2003. Den dag lod præsident Vladimir Putin forretningsmanden Mikhail Khodorkhovskij arrestere, og den dag forstod de ukrainske oligarker, hvad de kunne vente sig af en genforening med Rusland.

Selv om man i Kreml og rundt på de russiske barer ikke har vænnet sig til, at 'Lille-Rusland' er selvstændigt, er den sag vundet af de ukrainske nationalister.

Men Jusjtjenko formåede ikke at sætte handling bag sit ønske om integration vestover. Forlydender om et møde umiddelbart efter Justjtjenkos valgsejr ved omvalget 2004-05 mellem ham om en række EU-repræsentanter passer fint til hans regeringsstil. "Til lykke med valget. Hvad kan vi gøre for dig?" lød EUfolkenes spørgsmål til helten fra Den Orange Revolution. Jusjtjenko lagde højtideligt hånden på hjertet og svarede: "Bevare Ukraine i jeres hjerter". "Naturligvis hr. præsident, men vi vil gerne gøre mere". Man kunne, lyder beretningen, høre knappenålen falde, da Viktor Jusjtjenko så bøjede sig lidt frem og sagde: "Det er det vigtigste".

Men hvad får man så i stedet? En russisk trojansk hest?

Jusjtjenko stillede offentligt spørgsmålet, da valgkommissionen havde offentliggjort det endelige valgresultat. $\mathrm{Og}$ Janukovitj svarede pronto i et interview med InterfaxUkraine:

"Til dem, der venter at mit præsidentskab vil svække Ukraine, har jeg kun et at sige: Det får I ikke at se. Jeg har tilstrækkelig styrke og konsekvens til at forsvare Ukraines interesser i forholdet til alle partnere og alle naboer. Hvert skridt, jeg tager, vil sigte på at styrke Ukraines uafhængighed og at opbygge en stærk stat med en høj levestandard for befolkningen".

$\mathrm{Nu}$ siger politikere jo så meget, $\mathrm{og}$ Viktor Janukovitj ses - især i international presse - som 'Moskvavenlig'. For denne mærkat taler for eksempel, at han har udtalt sig for at anerkende de to georgiske løsrivelsesrepublikker Abkhasien og Sydossetien. For taler også, at Ruslands præsident Dmitrij Medvedev har sagt, at Rusland godt kan samarbejde med ham.

\section{Sortehavsflåden kan blive}

Efter valgsejren bebudede Janukovitj, at russerne kan få forlænget kontrakten om basen for Sortehavsflåden i Sevastopol på Krim, når den udløber i 2017.

Krim er et af Ukraines ulmende nationalistiske problemer. Et flertal af halvøens beboere ønsker genforening med Rusland. Man kan derfor spørge, om det ikke var klogt at sluk- 
ke lunten på en af bomberne. Ukraine har ikke behov for basen. Det har russerne sådan set heller ikke. De har bare ikke indset det. Men russerne bringer penge til Sevastopol, hvor der ikke er megen anden økonomisk aktivitet, og en forlængelse lægger selvstændighedsdiskussionen på Krim i frostboksen.

Janukovitj har også udtalt sig til fordel for Ukraines deltagelse i Ruslands, Hvideruslands og Kasakhstans fælles toldunion.

Så, jo. Han er mere Moskvavenlig end sin forgænger.

Men samtidig er der ikke tvivl om, at Janukovitj ønsker tilnærmelse til Vesteuropa og vil udbygge samarbejdet med EU.

Spørgsmålet om NATO blev nærmest ikke næunt i valgkampen, og det afspejler den udbredte folkelige skepsis. Ukrainerne ser sig som europæere og er positive over for EU. Men for dem er NATO et amerikansk foretagende, og det er en politisk tabersag.

Ukrainske kommentatorer har også fremhævet, at netop fordi Kreml ikke er bange for Janukovitj, kan han udenrigspolitisk gå længere end Jusjtjenko og Timosjenko. Timosjenkos forhold til Putin nåede at blive næsten hjertevarmt.

På grænsen mellem indenrigs- og udenrigspolitik er spørgsmålet om russisk. I den ukrainske forfatning er ukrainsk det nationale sprog, men da der i det østlige Ukraine stort set ikke tales ukrainsk, har Janukovitj foreslået at sidestille russisk og ukrainsk som officielle sprog.

Følger man hans udvikling fra 2004 til i dag er han blevet mere og mere ukrainsk og mindre og mindre 'kremlsk'.

Ukraine står i enorme økonomiske problemer og har måske brug for en mere grå præsident end den sprudlende Julia Timosjenko. Og grå, det er Viktor Janukovitj. Hans mange amerikanske rådgivere har lært ham at opføre sig pænere, at tale mere forståeligt og at gå bedre klædt. Men Ukraine har under alle omstændigheder fået en mere farveløs leder.

Henrik Kaufholz er journalist på Politiken og har siden 2003 besøgt Ukraine 45 gange om året som koordinator for det journalistiske netverk Scoop. 